Historic, Archive Document

Do not assume content reflects current scientific knowledge, policies, or practices. 



\section{CARR'S NURSERIES}

\section{SPECIAL}

We can supply, until exhausted, a few hundreds of the following specified and priced evergreens for spring trade 1927.

Thuya Pyramidalis Specimens

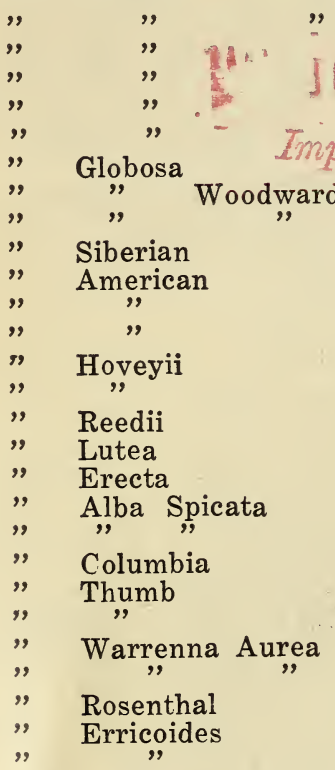

Juniperus Pfritzerianna,

$\begin{array}{ll}" & \text { Sabina } \\ " & \text { Stricta } \\ " & \text { Sinensis Var. }\end{array}$

Retinospora Plumosa

" " " " Aurea

Spruce Norway.

\begin{tabular}{|c|c|c|c|}
\hline & & & 850 \\
\hline & $41 / 2$ & $\mathrm{ft}$ & $\begin{array}{r}\$ .50 \\
4.50\end{array}$ \\
\hline & 4 & ft. & 4.00 \\
\hline & 4 & ft. & 3.50 \\
\hline & $31 / 2$ & ft. & 3.00 \\
\hline & 3 & ft. & \\
\hline & $2-3$ & ft. & 2.50 \\
\hline & $18-24$ & in. & 2.00 \\
\hline & $\begin{array}{c}15-18 \\
18-24\end{array}$ & in. & 2.00 \\
\hline & $15-18$ & in. & 1.00 \\
\hline & $4-5$ & ft. & 2.50 \\
\hline & $3-4$ & $\mathrm{ft}$. & 2.00 \\
\hline & $2-3$ & ft. & 1.00 \\
\hline & 2 & $\mathrm{ft}$. & 2.00 \\
\hline & $21 / 2$ & ft. & 2.50 \\
\hline & $12-15$ & in. & 1.75 \\
\hline & $12-15$ & in. & 1.00 \\
\hline & $18-24$ & in. & 2.00 \\
\hline & $2-3$ & ft. & 2.00 \\
\hline & $15-18$ & in. & 1.00 \\
\hline & $15-18$ & in. & 1.25 \\
\hline & $12-15$ & in. & 1.00 \\
\hline & $15-18$ & in. & 1.25 \\
\hline & $12-15$ & in. & 1.50 \\
\hline & $15-18$ & in. & 2.00 \\
\hline & & ft. & 2.50 \\
\hline & $12-15$ & in. & 1.00 \\
\hline & $15-18$ & in. & 1.25 \\
\hline ads & $3-4$ & ft. & 3.50 \\
\hline & & ft. & 3.00 \\
\hline & $15-18$ & in. & 1.50 \\
\hline & $18-24$ & in. & 2.00 \\
\hline & $18-24$ & in. & 2.00 \\
\hline & $15-18$ & in. & 1.75 \\
\hline & $18-24$ & in. & 2.00 \\
\hline & $12-15$ & in. & 1.00 \\
\hline & $15-18$ & in. & 1.25 \\
\hline & $12-15$ & in. & 1.25 \\
\hline & $10-$ & $\begin{array}{l}\text { in. } \\
\text { in. }\end{array}$ & $\begin{array}{r}1.50 \\
.50\end{array}$ \\
\hline & $15-18$ & in & .75 \\
\hline
\end{tabular}

NEW VARIETIES

Juniperus Virginiana Jamestown Thuya Dark Green American

18-24 in. $\quad 3.00$ $3 \mathrm{ft} . \quad 3.00$

\section{ALL STOCK ABOVE BALLED AND BURLAPED}


These trees are true to type, and densely foliaged and rooted, owing to care and occasional deep cultivation. Our own produ.ct; with many years' experience as propagators. A persona! inspection is always more satisfactory to the purchaser, but we will express samples F. O. B. Yellow Springs, when cash at wholesale price accompanies the request.

\section{L. CARR'S SONS Yellow Springs, Ohio.}

LIBFARY BDOKITEO * JUL $61931 \star$ (Over)

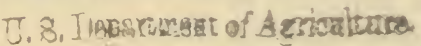

